\title{
ストッパー機構を有する二関節ホッピングロボットの動的解析*
}

\author{
小島 宏 行*1, Gustavo KATO*2
}

\section{Dynamic Analysis of Two-Link Hopping Robot with Stopper Mechanisms}

\author{
Hiroyuki KOJIMA*3 and Gustavo KATO \\ ${ }^{* 3}$ Department of Mechanical System Engineering, Gunma University, \\ 151 Tenjincho, Kiryu shi, Gunma, 376-8515 Japan
}

\begin{abstract}
In this paper, the dynamic behaviors of a two-link hopping robot with two stopper mechanisms are investigated theoretically. In the theoretical analysis, the dynamic behaviors of the two-link hopping robot with two stopper mechanisms are modeled by use of the four phases (phase- $\mathrm{A}$, phase$B$, phase $C$, phase- D). At the moment when the first joint stops, the state of the system transfers from phase $A$ to phase- $B$. Then, at the moment when the second joint stops, the state of the system transfers from phase $B$ to phase $C$. In phase- $C$, the two-link hopping robot moves in space, and at the moment when the two link hopping robot lands, the state of the system transfers from phase ${ }^{-} \mathrm{C}$ to phase- $\mathrm{D}$. Using the principle of the conservation of momentum and angular momentum, the initial states in the periods of phase $\mathrm{B}$ and phase- $\mathrm{C}$ are derived, and the equations of motion of the two-link hopping robot in all phases are obtained. Furthermore, the numerical simulations have been carried out, and it is confirmed theoretically that the hopping and moving action can be performed successfully.
\end{abstract}

Key Words: Robot, Dynamics of Machinery, Modeling, Shock, Motion Control, Two-Link Hopping Robot, Stopper Mechanism, Hopping and Moving Action

\section{1. 緒言}

自然界では，行動範囲が広く，高速移動ができ る生物が存在し，これらの生物においては，移動 中に宙に浮き揚がるような跳躍運動を行うことに より高速移動を実現している場合が少なくない. このような跳躍運動を工学的に実現し, 移動ロボ ットの作業能力をより多機能化することを意図し たホッピングロボットに関する研究が行われてい る(1). 例えば, 反復跳躍機構の基本的モデルにつ いての反復跳躍運動の可制御性と安定性(2), 空圧 アクチュエータとジャイロセンサを用いた一本足 ホッピングロボットによるホッピング動作の実現 (3)，空圧アクチュエータにより跳躍機能を実現す るとともに，DC モータを用いて姿勢制御を行う 型式の跳躍移動ロボット(4), DC モータと歯車を 用いてばねにポテンシャルエネルギーを蓄え，こ のエネルギーを瞬間的に開放することによる跳躍 運動の実現(5), 跳躍ロボットの胴体部の最適ソフ トランディングの定義に基づく胴体部の軌道制御

* 原稿受付 2004 年 8 月 9 H.

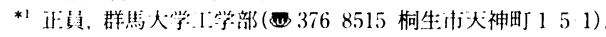

*2 群馬大学大学院。

E mail : kojima (a me.gunma u.ac.jp
によるソフトソフトランディングの実現(6)な゙に関 する研究が報告されている.

また，4面包囲型りニア直流モータと支持ばねを 用いたホッピングロボットによる連続跳躍(およよひ跳 躍移動(8を行った研究，小出力のアクチュエータを用 いた跳躍運動の実現方法として, 系の固有振動数を 考慮し，ばね質量系を加振することにより，短時間 で大きなエネルギーをばねに蓄える手法に基づく跳 躍機械に関する研究(9)が行われている.ささらに, 神経 振動子に基づく適応的周期加振力を用いたホッピン グロボットに関する研究(10)，第 2 関節のみに DC モ 一タを搭載した二リンクホッピングロボットを試作 するとともに，第 2 リンクの回転運動を用いてホッ ピング動作を実現した研究(11が報告されている.

一方, ゴルフスイングロボットのハイパーダイナ ミックス動作において，永久磁石を用いたストッパ 一機構によって関節の運動範囲の制限を行うことに より，効率のよい加速を実現した研究(12)が行われて いる．人間の関節の運動範囲においても制限がある ことから，ストッパー機構を有する多関節ホッピン グロボットによりホッピング動作を実現することは 興味あることと言える。このような観点から，スト ッパー機構を有する二関節ホッピングロボットに関 する実験的な研究が行われており，ストッパー機 
構による撃力を効果的に用いた跳躍移動運動動作 が実現し得ることを実験的に立証した研究(13)が報 告されている:この研究においては, 図 1 のよう な二関節ホッピングロボットの第 1 関節と第 2 関 節を，ストッパー機構を用いて順次急停止させる ことによりホッピング動作を実現している。各関 節には, ギヤボックス内蔵の DC モータが搭載さ れており, 最大の撃力を発生させるために, 許容 最大電圧近傍の電圧で DC モータが駆動されてい る、また，ホッピング動作を実現させるためのス トッパー機構の設定角度, 関節角の初期值, およ び DC モータの印加電圧遅れ時間などのパラメー 夕を試行錯誤的に見出している。実験結果より, 二関節ホッピングロボットは, 図 2 に示されてい るように，基礎リンク下左右部接地状態（A 相）， 基礎リンク下左部接地状態（B 相），空中浮遊状 態 (C 相)，基礎リンク下右部接地状態（D 相） の順にホッピング動作を行うことが確かめられて いる、しかしながら, 系の動的応答の理論的な解 明については，未だ行われておらず，この種のホ ッピングロボットの設計指針を得るためには, 系 の動的挙動を理論的に明らかにすることが重要で あるものと言える。

本研究は，既報の実験結果(13)に鑑み，ストッパ 一機構を有する二関節ホッピングロボットの動的 挙動を， $\mathrm{A}$ 相， B 相， C 相及び D 相の四つの相に 分けてモデル化している. ストッパー機構を有す る二関節ホッピングロボットは，二つの関節と三 つのリンクから構成されている.二つの関節には, 直流モータ, 減速歯車, ストッパー機構, ポテン ショメータが搭載されている。系の動的挙動の理 論解析では, 各リンクの運動量と角運動量の保存 の法則を用いて, 各相における系の初期状態を導 出するとともに，各相における系の運動方程式を 導いている.さらに, 数值シミュレーションを行 い，ストッパー機構を有する二関節ホッピングロ ボットの動的挙動の一端を調べている.

\section{2. 系の動的挙動の理論解析}

\section{1 系の座標モデル}

図 1 は, ストッ パー機構を有する二関節ホッピングロボットの座 標モデルを示したものである。本研究では，既報 の実験結果(13)に鑑み，系の動的挙動を，図 2 に示 されているように，A相，B相，C相及び D 相の 四つの相に分けてモデル化する.この図は, $t=t_{A}$ で第 1 関節の回転運動が急停止し， $t=t_{B}$ で 第 2 関節の回転運動が急停止するとともに，二関 節ホッピングロボットが，空中浮遊運動を開始す ることを表わしている．その後， $t=t_{C}$ で二関節

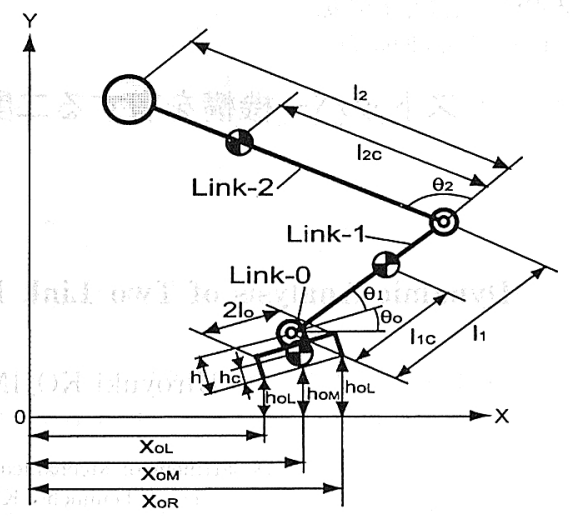

Fig.1 Schematic model of two-joint hopping robot
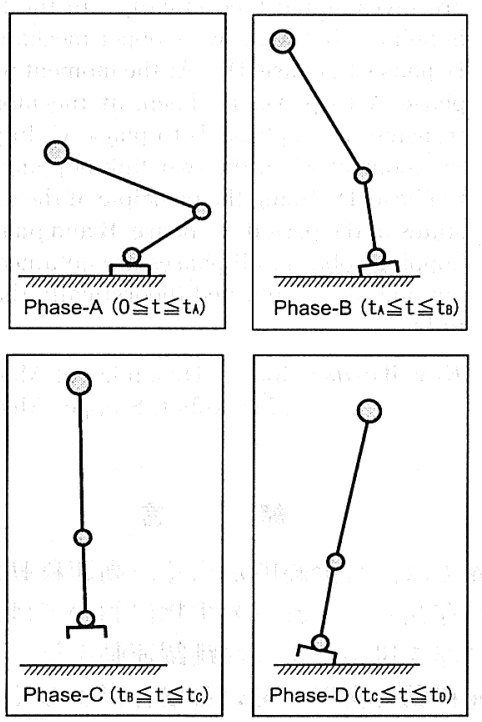

Fig.2 Dynamic behaviors of four phases

ホッピングロボットが着地し， $t=t_{D}$ において全 動作を終了することが示されている.

2. $2 \mathrm{~A}$ 相における系の運動方程式 $\mathrm{A}$ 相 は，二関節ホッピングロボットの動作開始時から， 第 1 関節の回転運動が急停止までの期間に対応し ている、A 相における系の運動方程式は, 図 2 中 の記号を用いると，次式のように書くことができ る.

$$
\left[\begin{array}{ll}
J_{A 11} & J_{A 12} \\
J_{A 21} & J_{A 22}
\end{array}\right]\left[\begin{array}{l}
\ddot{\theta}_{1} \\
\ddot{\theta}_{2}
\end{array}\right]+\left[\begin{array}{l}
h_{A 1} \\
h_{A 2}
\end{array}\right]=\left[\begin{array}{l}
K_{1} v_{1} \\
K_{2} v_{2}
\end{array}\right]
$$

ここに

$$
\begin{gathered}
J_{A 11}=N_{1}^{2} J_{A 1}+J_{c 1}+J_{c 2}+m_{1} l_{c 1}^{2} \\
+m_{2}\left(l_{1}^{2}+l_{c 2}^{2}+2 l_{1} l_{c 2} C_{2}\right) \\
J_{A 12}=J_{A 21}=J_{c 2}+m_{2}\left(l_{c 2}^{2}+l_{1} l_{c 2} C_{2}\right)
\end{gathered}
$$




$$
\begin{aligned}
J_{A 22}= & N_{2}^{2} J_{A 2}+J_{c 2}+m_{2} l_{c 2}^{2} \\
h_{A 1}= & -m_{2} l_{1} l_{c 2}\left(2 \dot{\theta}_{1} \dot{\theta}_{2}+\dot{\theta}_{2}^{2}\right) S_{2}+m_{1} l_{c 1} g C_{1} \\
& +m_{2} g\left(l_{1} C_{1}+l_{c 2} C_{12}\right)+\left(c_{d 1}+c_{K 1}\right) \dot{\theta}_{1} \\
h_{A 2}= & m_{2} l_{1} l_{c 2} S_{2} \dot{\theta}_{1}^{2}+m_{2} l_{c 2} g C_{12} \\
& +\left(c_{d 2}+c_{K 2}\right) \dot{\theta}_{2}
\end{aligned}
$$

式(2)〜 (6) 中の記号は次式のように定義されてい る

$$
\begin{aligned}
& K_{1}=\frac{N_{1} K_{T 1}}{R_{1}}, \quad K_{2}=\frac{N_{2} K_{T 2}}{R_{2}} \\
& c_{K 1}=\frac{N_{1}^{2} K_{T 1} K_{t: 1}}{R_{1}}, \quad c_{K 2}=\frac{N_{2}^{2} K_{T 2} K_{E 2}}{R_{2}} \\
& C_{1}=\cos \theta_{1}, C_{2}=\cos \theta_{2}, \quad S_{2}=\sin \theta_{2} \\
& C_{12}=\cos \left(\theta_{1}+\theta_{2}\right)
\end{aligned}
$$

ここに, $\theta_{1}, \theta_{2}$ は関節角， $m_{1}, m_{2}$ は各リンクの質量, $l_{1}, l_{2}$ は各リンクの長さ, $J_{c 1}, J_{c 2}$ は各リンクの重心 回りの慣性モーメント， $l_{c 1}, l_{c 2}$ は各リンクの関節 中心と重心位置の距離, $N_{1}, N_{2}$ は減速機の減速比, $J_{A 1}, J_{A 2}$ は直流モータのロータの慣性モーメント, $K_{T 1}, K_{T 2}$ は直流モータのトルク定数, $K_{t: 1}, K_{t: 2}$ は 逆起電力係数, $R_{1}, R_{2}$ は電機子の抵抗, $c_{d 1}, c_{d 2}$ は 各関節部の粘性減衰係数, $g$ は重力定数である.

\section{2. $3 \mathrm{~A}$ 相から B 相への移行直後の系の状態}

時間 $t=t_{A}$ の瞬間に第 1 関節の回転運動が急停 止すると, 系は $\mathrm{A}$ 相から B 相に移行し, 基礎り ンクと第 1 リンクは，一体化したリンク L - 01 として運動するが，第 2 関節は連続的に回転運動 を継続する，一体化したリンク L-01 は, 図 2 中の基礎リンクの姿勢角 $\theta_{0}$ によって記述できる。

$\mathrm{A}$ 相から B 相へ移行直後のリンク L - 01 の回 転角速度の值は, 系の角運動量保存の法則(14)を用 いて，以下のような手順で導くことができる.

第 1 関節が急停止する直前の系の角運動量は, 次式のように書くことができる.

$$
L\left(t_{A}-\varepsilon\right)=L_{1 A m}+L_{2 A m}
$$

ここに， $\varepsilon$ は限りなく小さな正の実数であり， $L_{1 A m}, L_{2 A m}$ は次式のように定義されている.

$$
\begin{gathered}
L_{1 A m}=\left(\begin{array}{c}
\left.J_{c 1}+N_{1} J_{A 1}\right) \dot{\theta}_{1 A} \\
+m_{1}\left(x_{c 1 A} \dot{y}_{c 1 A}-y_{c 1 A} \dot{x}_{c 1 A}\right)
\end{array}\right. \\
L_{2 A m}=J_{c 2} \dot{\theta}_{1 A}+\left(J_{c 2}+N_{2} J_{c 2}\right) \dot{\theta}_{2 A} \\
\quad+m_{2}\left(x_{c 2 A} \dot{y}_{c 2 A}-y_{c 2 A} \dot{x}_{c 2 A}\right) \\
\dot{\theta}_{1 A}=\dot{\theta}_{1}\left(t_{A}-\varepsilon\right), \quad \dot{\theta}_{2 A}=\dot{\theta}_{2}\left(t_{A}\right) \\
x_{c 1 A}=l_{o}+l_{c 1} C_{1 A}, \quad y_{c 1 A}=h+l_{c 1} S_{1 A} \\
x_{c 2 A}=l_{o}+l_{1} C_{1 A}+l_{c 2} C_{12 A} \\
y_{c 2 A}=h+l_{1} S_{1 A}+l_{c 2} S_{12 A} \\
\dot{x}_{c 1 A}=-l_{c 1} S_{1 A} \dot{\theta}_{1 A}, \quad \dot{y}_{c 1 A}=l_{c 1} C_{1 A} \dot{\theta}_{1 A}
\end{gathered}
$$

$$
\begin{aligned}
& \dot{x}_{c 2 A}=-\left(l_{1} S_{1 A}+l_{c 2} S_{12 A}\right) \dot{\theta}_{1 A}-l_{c 2} S_{12 A} \dot{\theta}_{2 A} \\
& \dot{y}_{c 2 A}=\left(l_{1} C_{1 A}+l_{c 2} C_{12 A}\right) \dot{\theta}_{1 A}+l_{c 2} C_{12 A} \dot{\theta}_{2 A} \\
& C_{1 A}=\cos \theta_{1 A}, \quad S_{1 A}=\sin \theta_{1 A} \\
& C_{12 A}=\cos \left(\theta_{1 A}+\theta_{2 A}\right) \\
& S_{12 A}=\sin \left(\theta_{1 A}+\theta_{2 A}\right) \\
& \theta_{1 A}=\theta_{1}\left(t_{A}\right), \quad \theta_{2 A}=\theta_{2}\left(t_{A}\right)
\end{aligned}
$$

また，第 1 関節の回転運動が急停止した直後の系 の角運動量は, 次式で記述できる.

$$
\begin{gathered}
L\left(t_{A}+\varepsilon\right)=\kappa_{A B 1} \dot{\theta}_{0}\left(t_{A}+\varepsilon\right)+\kappa_{A B 2} \\
こ こ に, \quad \\
\kappa_{A B 1}=J_{c o}+J_{c 1}+J_{c 2}+m_{o}\left(l_{o}^{2}+h_{c}^{2}\right) \\
+\sum_{i=1}^{2}\left(x_{c i A} \bar{y}_{c i A}-y_{c i A} \bar{x}_{c i A}\right) \\
\kappa_{A B 2}=\left\{J_{c 2}+N_{2} J_{A 2}\right. \\
\left.+m_{2}\left(x_{c 2 A} \bar{\beta}_{c 2 A}-y_{c 2 A} \bar{\alpha}_{c 2 A}\right)\right) \dot{\theta}_{2 A} \\
\bar{x}_{c 1 A}=-h-l_{c 1} S_{1 A}, \quad \bar{y}_{c 1 A}=l_{o}+l_{c 1} C_{1 A} \\
\bar{x}_{c 2 A}=-h-l_{1} S_{1 A}-l_{c 2} S_{12 A} \\
\bar{y}_{c 2 A}=l_{o}+l_{1} C_{1 A}+l_{c 2} C_{12 A} \\
\bar{\alpha}_{c 2 A}=-l_{c 2} S_{12 A}, \quad \bar{\beta}_{c 2 A}=l_{c 2} C_{12 A}
\end{gathered}
$$

であり， $\theta_{o}$ は基礎りンクの回転角， $m_{o}, J_{c o}$ は基礎 リンクの質量ならびに重心回りの慣性モーメント, $l_{o}, h, h_{c}$ は, 図 1 中に示されているような基礎リン クの寸法である.

第 1 関節の回転運動が急停止する瞬間 $\left(t=t_{A}\right)$ の 前後の系の角運動量の式 (11) と式 (25) を等値する と, B 相に移行直後のリンク L- 01 の回転角速度 の值 $\dot{\theta}_{o}\left(t_{A}+\varepsilon\right)$ は次式のように導かれる.

$$
\dot{\theta}_{o}\left(t_{A}+\varepsilon\right)=\frac{L\left(t_{A}-\varepsilon\right)-k_{A B 2}}{k_{A B 1}}
$$

2. 4 B 相における系の運動方程式 時間 $t=t_{A}$ の瞬間に第 1 関節の回転運動が急停止する と, 基礎リンクと第 1 リンクは一体化し, 系は $\mathrm{A}$ 相から B 相に移行する. B 相は, $t=t_{A}$ の瞬間に第 1 関節が急停止した瞬間から， $t=t_{B}$ の瞬間に第 2 関節が急停止する瞬間までの期間に対応し, 一 体化したリンク L - 01 は，基礎リンク下左部を 中心とする回転運動を行なう。この B 相における 系の運動方程式は, 次式のように書くことができ る.

$$
\begin{aligned}
& \text { ここに, } \\
& J_{B 11}=J_{c o 1}+J_{c 2}+m_{o 1} \eta_{B 1}+m_{2} \eta_{B 2} \\
& +2 m_{2}\left(l_{1} l_{c 2} C_{2}+l_{o} l_{c 2} C_{12}+h_{1} l_{c 2} S_{12}\right) \\
& J_{B 12}=J_{B 21}=J_{c 2}+m_{2} l_{c 2}^{2} \\
& +m_{2}\left(l_{1} l_{c 2} C_{2}+l_{o} l_{c 2} C_{12}+h_{1} l_{c 2} S_{12}\right) \\
& J_{B 22}=N_{2}^{2} J_{A 2}+J_{c 2}+m_{2} l_{c 2}^{2}
\end{aligned}
$$$$
\left[\begin{array}{ll}
J_{B 11} & J_{B 12} \\
J_{B 21} & J_{B 22}
\end{array}\right]\left[\begin{array}{l}
\ddot{\theta}_{o} \\
\ddot{\theta}_{2}
\end{array}\right]+\left[\begin{array}{c}
h_{B 1} \\
h_{B 2}
\end{array}\right]=\left[\begin{array}{c}
0 \\
K_{2} v_{2}
\end{array}\right]
$$ 


$$
\begin{aligned}
& h_{B 1}=m_{2} \kappa_{B 1}\left(2 \dot{\theta}_{o} \dot{\theta}_{2}+\dot{\theta}_{2}^{2}\right)+\kappa_{B 2} \\
& h_{B 2}=m_{2} \kappa_{B 1} \dot{\theta}_{o}^{2}+m_{2} g l_{c 2} C_{o 12}
\end{aligned}
$$

であり, 式中の記号は以下のように定義されてい る.

$$
\begin{aligned}
& m_{o 1}=m_{o}+m_{1} \\
& J_{c o 1}=J_{c o}+J_{c 1}+m_{o} p_{B o}^{T} p_{B o}+m_{1} p_{B 1}^{T} p_{B 1} \\
& p_{B o}=r_{c o}-r_{c o 1}, \quad p_{B 1}=r_{c 1}-r_{c o 1} \\
& r_{c o}=\left[\begin{array}{l}
l_{o} C_{o}-h_{c} S_{o} \\
l_{o} S_{o}+h_{c} C_{o}
\end{array}\right] \\
& r_{c 1}=\left[\begin{array}{l}
l_{o} C_{o}-h_{c} S_{o}+l_{c 1} C_{o 1} \\
l_{o} S_{o}+h_{c} C_{o}+l_{c 1} S_{o 1}
\end{array}\right] \\
& r_{c o 1}=\frac{1}{m_{o 1}}\left[\begin{array}{l}
\xi_{1} C_{o}-\xi_{2} S_{o}+m_{1} l_{c 1} C_{o 1} \\
\xi_{1} S_{o}+\xi_{2} C_{o}+m_{1} l_{c 1} S_{o 1}
\end{array}\right] \\
& \kappa_{B 1}=-l_{1} l_{c 2} S_{2}-l_{o} l_{c 2} S_{12}+h l_{c 2} C_{12} \\
& \kappa_{B 2}=g\left(\xi_{1} C_{o}-\xi_{2} S_{o}+m_{1} l_{c 1} S_{o 1}\right) \\
& \eta_{B 1}=\frac{\bar{\eta}_{B 1}}{\left(m_{o}+m_{1}\right)^{2}} \\
& \bar{\eta}_{B 1}=\xi_{1}^{2}+\xi_{2}^{2}+m_{1}^{2} l_{c 1}^{2} \\
& \quad+2 m_{1} l_{c 1}\left(\xi_{1} C_{1}+\xi_{2} S_{1}\right) \\
& \eta_{B 2}=m_{2}\left(l_{o}^{2}+h^{2}+l_{1}^{2}+l_{c 2}^{2}\right. \\
& \left.\quad+2 l_{o} l_{1} C_{1}+2 h l_{1} S_{1}\right) \\
& \xi_{1}=l_{o}\left(m_{o}+m_{1}\right), \quad \xi_{2}=m_{o} h_{c}+m_{1} h \\
& C_{o}=\cos \theta_{o}, \quad S_{o}=\sin \theta_{o}, \quad S_{1}=\sin \theta_{1} \\
& S_{o 1}=\sin \left(\theta_{o}+\theta_{1}\right), \quad S_{12}=\sin \left(\theta_{1}+\theta_{2}\right) \\
& C_{o 12}=\cos \left(\theta_{o}+\theta_{1}+\theta_{2}\right)
\end{aligned}
$$

ただし， $\theta_{1}=\theta_{1 A}$ である.

2. $5 \mathrm{~B}$ 相から $\mathrm{C}$ 相への移行直後の系の状態 時間 $t=t_{B}$ の瞬間に第 2 関節の回転運動が急停 止すると, 系は $\mathrm{B}$ 相から $\mathrm{C}$ 相に移行し, 基礎リ ンク，第 1 リンク及び第 2 リンクは一体化したリ ンク L- 012 として, 図 2 に示されているような 空中浮遊運動を行なう。

$\mathrm{B}$ 相から C 相へ移行直後のリンク L-012の並 進速度は, 運動量保存の法則(14)を用いて, 以下の ような手順で導くことができる.

本研究で取り扱っている二関節ホッピングロボ ットは，鉛直面内で運動を行なっている．第 2 関 節の回転運動が急停止する直前の系の鉛直面内 $(x-y$ 平面) の運動量は, 次式のように書くこ とができる.

$$
P\left(t_{B}-\varepsilon\right)=\left[\begin{array}{l}
m_{o} \dot{x}_{c o B}+m_{1} \dot{x}_{c 1 B}+m_{o} \dot{x}_{c 2 B} \\
m_{o} \dot{y}_{c o B}+m_{1} \dot{y}_{c 1 B}+m_{o} \dot{y}_{c 2 B}
\end{array}\right]
$$

ここに,

$$
\begin{aligned}
& \dot{x}_{c o B}=-\dot{\theta}_{o B}\left(l_{o} S_{o B}+h_{c} C_{o B}\right) \\
& \dot{y}_{c o B}=\dot{\theta}_{o B}\left(l_{o} C_{o B}-h_{c} S_{o B}\right) \\
& \dot{x}_{c 1 B}=-\dot{\theta}_{o B}\left(l_{o} S_{o B}+h C_{o B}+l_{c 1} S_{o 1 B}\right)
\end{aligned}
$$

$$
\begin{aligned}
& \dot{y}_{c 1 B}=\dot{\theta}_{o B}\left(l_{o} C_{o B}+h S_{o B}-l_{c 1} C_{o 1 B}\right) \\
& \dot{x}_{c 2 B}=-\left(l_{o} S_{O B}+h C_{o B}+l_{1} S_{O 1 B}\right) \dot{\theta}_{O B} \\
& -l_{c 2} S_{o 12 B}\left(\dot{\theta}_{o B}+\dot{\theta}_{2 B}\right) \\
& \dot{y}_{c 2 B}=\left(l_{o} C_{o B}-h S_{o B}+l_{1} C_{o 1 B}\right) \dot{\theta}_{o B} \\
& +l_{c 2} C_{o 12 B}\left(\dot{\theta}_{o B}+\dot{\theta}_{2 B}\right) \\
& \dot{\theta}_{o B}=\dot{\theta}_{o}\left(t_{B}\right), \quad \dot{\theta}_{2 B}=\dot{\theta}_{2}\left(t_{B}-\varepsilon\right) \\
& C_{o B}=\cos \left(\theta_{O B}\right), \quad S_{o B}=\sin \left(\theta_{o B}\right) \\
& C_{O 1 B}=\cos \left(\theta_{O B}+\theta_{1 A}\right), \quad S_{O \mid B}=\sin \left(\theta_{O B}+\theta_{1 A}\right) \text { (63) } \\
& C_{o 12 B}=\cos \left(\theta_{o B}+\theta_{1 A}+\theta_{2 B}\right) \\
& S_{o 12 B}=\sin \left(\theta_{o B}+\theta_{1 A}+\theta_{2 B}\right) \\
& \theta_{O B}=\theta_{o}\left(t_{B}\right), \quad \theta_{2 B}=\theta_{2}\left(t_{B}\right)
\end{aligned}
$$

第 2 関節の回転運動が急停止する直前の系の角運 動量は，次式のように記述できる。

$$
\begin{aligned}
& L\left(t_{B}-\varepsilon\right)=L_{o B m}+L_{1 B m}+L_{2 B m} \\
& \text { ここに } \\
& L_{O B m}=J_{c o} \dot{\theta}_{O B}+m_{o}\left(x_{C O B} \dot{y}_{C O B}-y_{C O B} \dot{x}_{c o B}\right) \\
& L_{1 B m}=J_{c 1} \dot{\theta}_{o B}+m_{1}\left(x_{c 1 B} \dot{y}_{c 1 B}-y_{c 1 B} \dot{x}_{c 1 B}\right) \\
& L_{2 B m}=J_{c 2}\left(\dot{\theta}_{O B}+\dot{\theta}_{2 B}\right) \\
& +m_{2}\left(x_{c 2 B} \dot{y}_{c 2 B}-y_{c 2 B} \dot{x}_{c 2 B}\right) \\
& x_{C O B}=l_{O} C_{O B}-h_{c} S_{O B} \\
& y_{C O B}=l_{O} S_{O B}+h_{C} C_{O B} \\
& x_{c 1 B}=l_{o} C_{o B}-h S_{o B}+l_{c 1} C_{o 1 B} \\
& y_{C 1 B}=l_{o} S_{O B}+h C_{O B}+l_{c 1} S_{O 1 B} \\
& x_{c 2 B}=l_{O} C_{O B}-h S_{o B}+l_{c 1} C_{O 1 B}+l_{c 2} C_{o 12 B} \\
& y_{c 2 B}=l_{O} S_{O B}+h C_{O B}+l_{c 1} S_{O 1 B}+l_{c 2} S_{O 12 B}
\end{aligned}
$$

また，第 2 関節の回転運動が急停止した直後の系 の鉛直面内の運動量は，次式のように書くことが できる。

$$
P\left(t_{B}+\varepsilon\right)=m\left[\begin{array}{l}
\dot{x}_{c}\left(t_{B}+\varepsilon\right) \\
\dot{y}_{c}\left(t_{B}+\varepsilon\right)
\end{array}\right]
$$

ここに,

$$
m=m_{o}+m_{1}+m_{2}
$$

であり， $x_{c}, y_{c}$ はリンク $\mathrm{L}-012$ の重心位置の座 標を表している，時間 $t=t_{B}$ における $x_{c}, y_{c}$ の値 $x_{c B}, y_{c B}$ は次式で与えられる.

$$
\left[\begin{array}{l}
x_{c B} \\
y_{c B}
\end{array}\right]=\frac{1}{m}\left[\begin{array}{l}
m_{o} x_{C O B}+m_{1} x_{c 1 B}+m_{2} x_{c 2 B} \\
m_{o} y_{c o B}+m_{1} y_{c 1 B}+m_{2} y_{c 2 B}
\end{array}\right]
$$

上式を用いると，第 2 関節の回転運動が急停止し た直後の系の角運動量は, 次式のように記述でき る.

$$
\begin{gathered}
\begin{array}{c}
L\left(t_{B}+\varepsilon\right)=J_{c B} \dot{\theta}_{c}\left(t_{B}+\varepsilon\right) \\
+m\left\{x_{c B} \dot{y}_{c}\left(t_{B}+\varepsilon\right)-y_{c B} \dot{x}_{c}\left(t_{B}+\varepsilon\right)\right\}
\end{array} \\
こ こ に, \quad \\
J_{c B}=J_{c o}+J_{c 1}+J_{c 2}+m_{o} p_{c o}^{T} p_{c o} \\
+m_{1} p_{c 1}^{T} p_{c 1}+m_{2} p_{c 2}^{T} p_{c 2}
\end{gathered}
$$




$$
\begin{aligned}
& p_{c o}=\left[\begin{array}{l}
x_{c B}-x_{c O B} \\
y_{c B}-y_{c o B}
\end{array}\right], \quad p_{c 1}=\left[\begin{array}{l}
x_{c B}-x_{c 1 B} \\
y_{c B}-y_{c 1 B}
\end{array}\right] \\
& p_{c 2}=\left[\begin{array}{l}
x_{c B}-x_{c 2 B} \\
y_{c B}-y_{c 2 B}
\end{array}\right]
\end{aligned}
$$

第 2 関節の回転運動が急停止する瞬間 $\left(t=t_{B}\right)$ の 前後の系の運動量の式(54) と式 (77) を等值すると, 第 2 関節が急停止した直後のリンク L- 012 の速 度は次式のように導かれる。

$$
\left[\begin{array}{l}
\dot{x}_{c}\left(t_{B}+\varepsilon\right) \\
\dot{y}_{c}\left(t_{B}+\varepsilon\right)
\end{array}\right]=\frac{1}{m} P\left(t_{B}-\varepsilon\right)
$$

また，第 2 関節の回転運動が急停止する瞬間 $\left(t=t_{B}\right)$ の前後の系の角運動量の式 (67) と式(80)を 等值すると，第 2 関節の回転運動が急停止した直 後のリンク $\mathrm{L}-012$ の角速度は次式のように得ら れる.

$$
\begin{gathered}
\dot{\theta}_{c}\left(t_{B}+\varepsilon\right)=\frac{1}{J_{c B}}\left[L\left(t_{B}-\varepsilon\right)-m\left\{x_{c B} \dot{y}_{c}\left(t_{B}+\varepsilon\right)\right.\right. \\
\left.\left.-y_{c B} \dot{x}_{c}\left(t_{B}+\varepsilon\right)\right\}\right]
\end{gathered}
$$

\section{2. $6 \mathrm{C}$ 相及 $\mathrm{D}$ 相における系の運動}

時間 $t=t_{B}$ の瞬間に第 2 関節の回転運動が急停 止すると, 系は $\mathrm{B}$ 相から $\mathrm{C}$ 相に移行する. C 相 は, $t=t_{B}$ の瞬間に第 2 関節の回転運動が急停止 し，一体化したリンク L-012 が空中浮揚運動を 開始し，基礎リンク下左部が着地する瞬間までの 期間に対応する。C 相における系の運動は，一体 化したリンク L - 012 の重心座標 $\left(x_{c}, y_{c}\right)$ を用いる と, 次式で記述される.

$$
\begin{aligned}
& x_{c}=x_{c B}+\left(t-t_{B}\right) \dot{x}_{c}\left(t_{B}+\varepsilon\right) \\
& y_{c}=y_{c B}+\left(t-t_{B}\right) \dot{y}_{c}\left(t_{B}+\varepsilon\right)-\frac{1}{2} g\left(t-t_{B}\right)^{2} \\
& \theta_{c}=\theta_{c}\left(t_{B}\right)+\left(t-t_{B}\right) \dot{\theta}_{c}\left(t_{B}+\varepsilon\right)
\end{aligned}
$$

図 3 に示されているように, 一体化したリンク L 012 が空中浮揚運動中に，基礎リンク下右部が着地す ると, 系は $\mathrm{C}$ 相から $\mathrm{D}$ 相に移行する. 二関節ホッピン グロボットが，空中浮揚運動状態から着地状態に移行 するときの衝突現象は複雑であるが,ここでは, 完 全非弾性衝突として取り扱うこととする. すなわち, 着地の際, 接地部は滑らずに, 系は接地点回りの回 転連動に移行し, 着地時間は極めて小さいものとす る.

一体化したリンク L-012の基礎リンク下右部回り の慣性モーメントを $J_{c R}$, 重力による基礎リンク下 右部回りのもモーメントを $f\left(\theta_{o}\right)$ とおくと, D 相にお ける系の運動方程式, 次式のように書くことができる.

$$
J_{c R} \ddot{\theta}_{o}-f\left(\theta_{o}\right)=0
$$

\section{3. 数値シミュレーション結果}
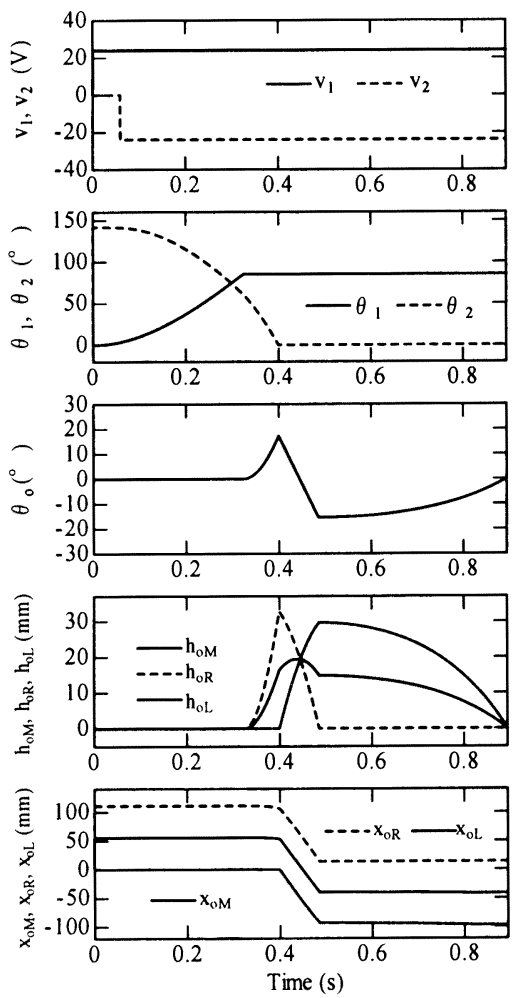

Fig.3 Dynamic response (Case-1)

の実験(13)において試作した二関節ホッピングロボ ツトと同一の值を用いてあり, $l_{o}=5.6 \mathrm{~cm}$, $h=2.6 \mathrm{~cm}, h_{c}=2.3 \mathrm{~cm}, h_{o}=1.1 \mathrm{~cm}, l_{c 1}=9.0 \mathrm{~cm}$, $l_{1}=10.0 \mathrm{~cm}, \quad l_{c 2}=19.8 \mathrm{~cm}, l_{2}=21.7 \mathrm{~cm}$, $m_{o}=0.26 \mathrm{~kg}, \quad m_{1}=0.26 \mathrm{~kg}, \quad m_{2}=0.167 \mathrm{~kg}$, $J_{c o}=3.6 \times 10^{-5} \mathrm{kgm}^{2}, \quad J_{c 1}=7.7 \times 10^{-4} \mathrm{kgm}^{2}, \quad J_{c 2}=$ $6.8 \times 10^{-3} \mathrm{kgm}^{2}, \quad J_{A 1}=J_{A 2}=1.45 \times 10^{-5} \quad \mathrm{kgm}^{2}$, $R_{1}=R_{2}=27 \Omega \quad, \quad K_{T 1}=K_{T 2}=0.043 \quad \mathrm{Nm} / \mathrm{A}$, $K_{E 1}=K_{E 2}=0.043 \mathrm{Vs} / \mathrm{rad}, N_{1}=50, N_{1}=20$ のとお りである.

$\mathrm{DC} モ ー タ の$ 制御電圧 $v_{1}, v_{2}$ は，既報の実験(13) と 同様に遅れ時間を用いて次式のように設定してい る.

$$
\begin{aligned}
& v_{1}=v_{\max } u_{s}\left(t-T_{d 1}\right) \\
& v_{2}=v_{\max } u_{s}\left(t-T_{d 2}\right)
\end{aligned}
$$

ここに, $u_{s}(t)$ は単位ステップ関数, $v_{\max }$ は最大電 圧, $T_{d 1}, T_{d 2}$ は遅れ時間であり, $v_{\max }=24 \mathrm{~V}$ とし ている.

図 3 は，ホッピング動作が実現し得る系のパラ メータの一つの例を試行錯誤的に求めて行った数 値シミュレーション結果の一例 (case-1) 示したも

数値シミュレーションで用いた系の諸元は，既報 


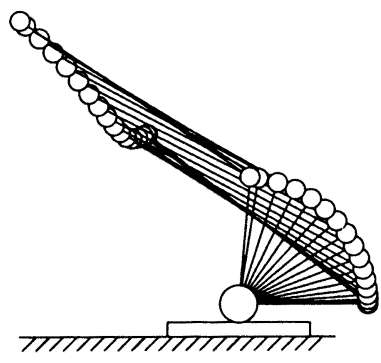

Fig.4 Loci in phase-A (Case-1)

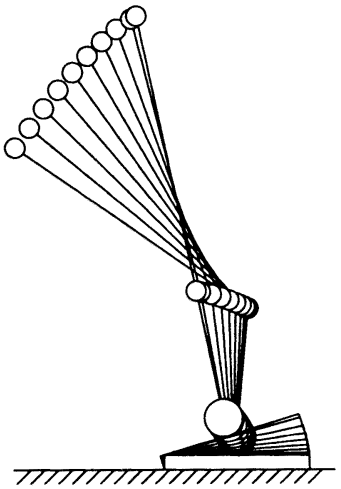

Fig. 5 Loci n phase-B (Case-1)

のである、ここでは，DC モータ印加電圧の遅れ 時間を $T_{d 1}=0, T_{d 2}=0.06 \mathrm{~s}$, 関節部の減衰係数を $c_{d 1}=0.05 \mathrm{Nms}, \quad c_{d 2}=0.001 \mathrm{Nms}$, 関節角の初期 值を $\theta_{1}(0)=0, \theta_{2}(0)=142^{\circ}$, ストッパー機構の設 定角度を $\theta_{1 s}=\theta_{1 A}=85^{\circ}, \theta_{2 s}=\theta_{2 B}=0$ としている. 図より, $t=t_{A}=0.323 \mathrm{~s}$ で第 1 関節の回転運動が 急停止するとともに，基礎リンクと第 1 リンクは 一体化し, 系は A 相から B 相に移行している. 一体化したリンク L-01 は, 撃力によって, 基 礎リンク下左部を中心とする回転運動を開始して いる. 図 4 と図 5 は， $\mathrm{A}$ 相及び B 相における系の 動的挙動の軌跡を示したものである.

次に, 図 3 より, $t=t_{B}=0.398 \mathrm{~s}$ で第 2 リンク が急停止し，基礎リンク，第 1 リンク，第 2 リン クは一体化するとともに, 系は B 相から $\mathrm{C}$ 相に 移行し, 一体化したリンク L-012 は, 空中浮遊 運動を開始していることがわかる.また，一体化 したリンク L - 012 の回転角速度は, 撃力によっ て正の值から負の值に急変するとともに, 一体化 したリンク L-012 は, 左方に移動運動を開始し ている. 図6は，C相における系の空中浮遊運動 の軌跡を示したものである.

さらに，図 3 より, $t=t_{C}=0.484 \mathrm{~s}$ で基礎りン ク下右部が着地し, 系は $\mathrm{C}$ 相から $\mathrm{D}$ 相に移行
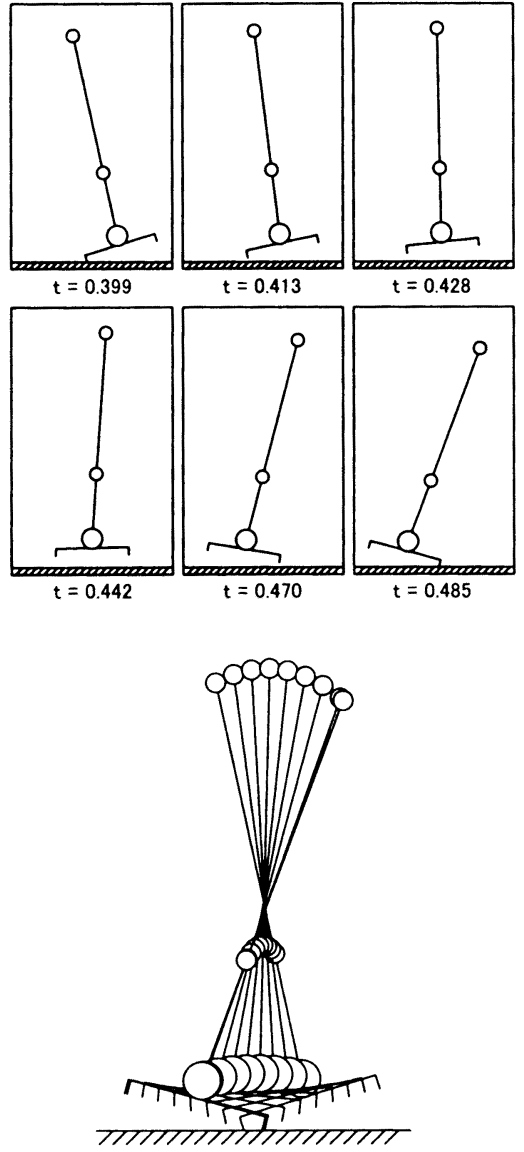

Fig.6 Loci in phase-C (Case-1)

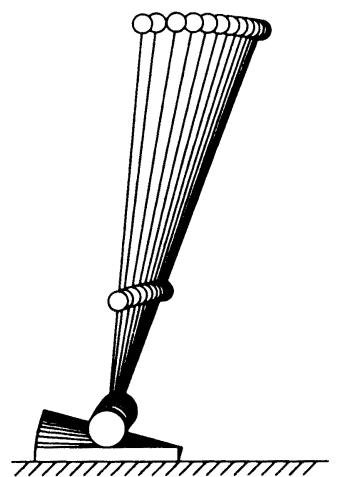

Fig. 7 Loci phase-D (Case-1)

し，一体化したリンク L- 012 は，基礎リンク下 右部を中心とする回転運動を開始している．系の運動 は, $t=t_{D}=0.914 \mathrm{~s}$ で終了している. 図7は, $\mathrm{D}$ 相に 


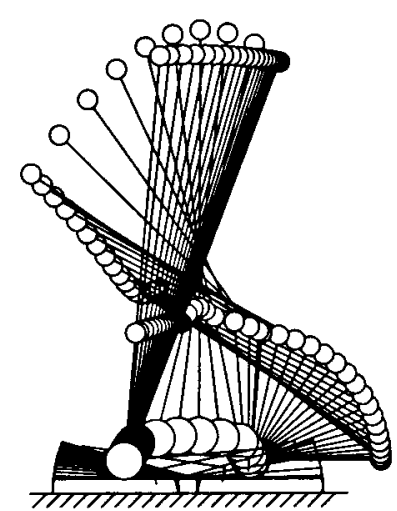

Fig. 8 Loci in all phases (Case-1)

おける系の回転運動の軌跡を示したものである. また図 8 は，系の動的挙動全体の軌跡を示した ものである.

\section{4. 実䖝結果 ${ }^{(3)}$ と数值シミュレーション結果との比較}

図 9 は，既報の実験(13)における系の動的応答を 示したものである.ここでは, ホッピング動作が 実現可能な系のパラメータとして， $T_{d 1}=0.024 \mathrm{~s}$, $T_{d 2}=0 \mathrm{~s}, \quad \theta_{1}(0)=0, \quad \theta_{2}(0)=155^{\circ}, \theta_{1 \mathrm{~s}}=80^{\circ}$, $\theta_{2 s}=0$ を試行錯誤的に求め実験を行っている. 図 10 は、この実験における画像を示したものであ る.なお，関節部においては，ギヤボックスなど に起因する複雑な非線形摩擦力が生起しているも のと思われる.

図 11 は，実験と同様，第 1 関節の DC モータ の印加電圧に遅れ時間がある場合の数値シミュレ ーン結果の一例(case-2)を示したものであり, 系 のパラメータの值は, $T_{d 1}=0.06 \mathrm{~s}, T_{d 2}=0 \mathrm{~s}$, $\theta_{1}(0)=0, \theta_{2}(0)=150^{\circ}, \theta_{1 s}=85^{\circ}, \theta_{2 s}=0$ としてい る.また, 関節部の減衰係数を $c_{d 1}=0.001 \mathrm{Nms}$, $c_{d 2}=0.068 \mathrm{Nms}$ としている. 図 12 は, 空中浮 遊運動の軌跡を示したものである.

実験結果と数值計算結果は, 両方とも，ストッ パー機構によって第 1 関節及び第 2 関節の回転運 動が順次急停止することによって，系の状態が A 相, B 相, C 相に遷移し，ホッピング動作が実現 されているという点で定性的に同様の動的举動を 示しているが，ストッパー機構の設定角度，関節 角の初期值, DC モータの印加電圧の遅れ時間, 時間応答特性などにおいて差異が喼められる。こ のことは, リンクの重心位置, 重心回りの正確な 值の測定が困難であることや，関節部のギヤボッ
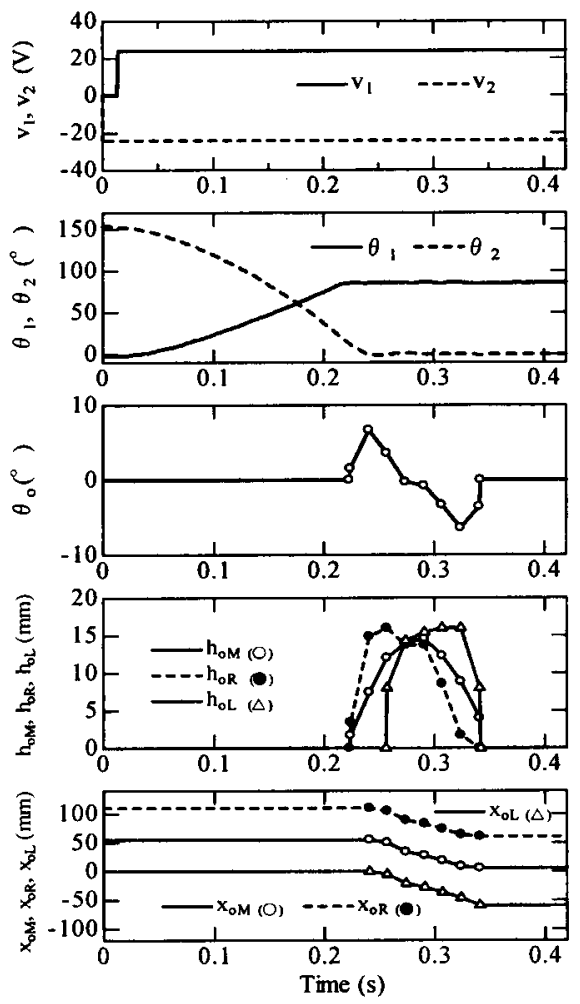

Fig.9 Previous experimental results of dynamic response ${ }^{(13)}$

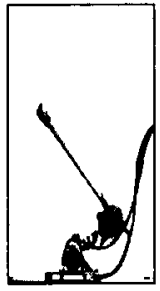

$t=0.096 \mathrm{~s}$

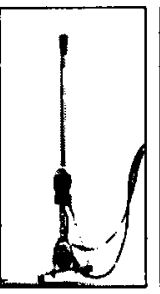

$\mathrm{t}=0.241 \mathrm{~s}$

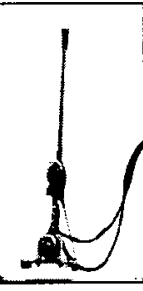

$t=0.291 \mathrm{~s}$

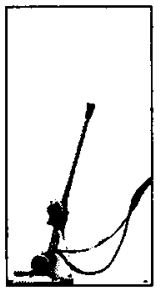

$t=0.341 \mathrm{~s}$
Fig. 10 Pictures of previous experimental results of dynamic response $\mathrm{e}^{(13)}$

クスなどに因る複雑な非線形摩擦力特性や衝突現 象等に起因しているものと考えられる.

\section{5. 結言}

本研究は、ストッパー機構を有する二関節ホッピ ングロボットの動的挙動の理論解析を行なうととも に, 数值シミュレーションを行ったものである. 系 の動的挙動の理論解析においては, 系の動的举動を, $\mathrm{A}$ 相，B 相，C 相及び D 相の四つの相に分けモデル 化するとともに，ストッパー機構によって第 1 関節及 び第 2 関節の回転云喠動が，順次急停止し，系が $\mathrm{A}$ 相か 

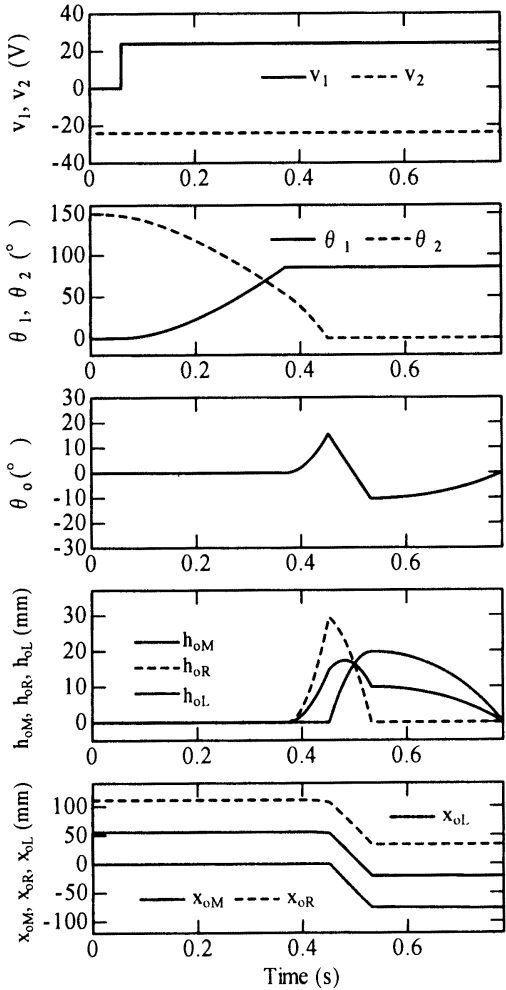

Fig.11 Dynamic response (Case-2)

ら B 相，および， B 相から C 相に移行する際の $\mathrm{B}$ 相および $\mathrm{C}$ 相の初期状態の式を, 系の運動量及 び角運動量保存の法則を用いて導いている。 また, 系の各相における運動方程式を求めている。 さら に, 数值シミュレーションを行なったところ, ス トッパー機構の設定角度, 関節角の初期值, DC モータの電圧印加遅れ時間などの系の適切パラメ 一夕を用いることにより，系の動的挙動は，既報 の実験結果と同様， $\mathrm{A}$ 相， B 相， C 相，D 相の状 態を遷移し，ストッパー機構を有する二関節ホッ ピングロボットの跳躍移動運動動作が良好に実現 し得ることが理論的に解明され，系の動的挙動の一端 が明らかにされた。

\section{文献}

（1）中野栄二，大久保宏樹，跳躍ロボット全般について 日本ロボット学会誌, 11-3, (1993), 342-347.

（2）松岡清利，跳躍・走行機構に関する基磷的研究，機論（第 1部)，43-376, (1977), 4501-4509.

(3) M. H. Raibert, H. B. Brown and M. Chepponis, Experiments in Balance with a 3D One-Legged Hopping Machine, The International Journal of Robotics, 3-2, (1984), 75-92.

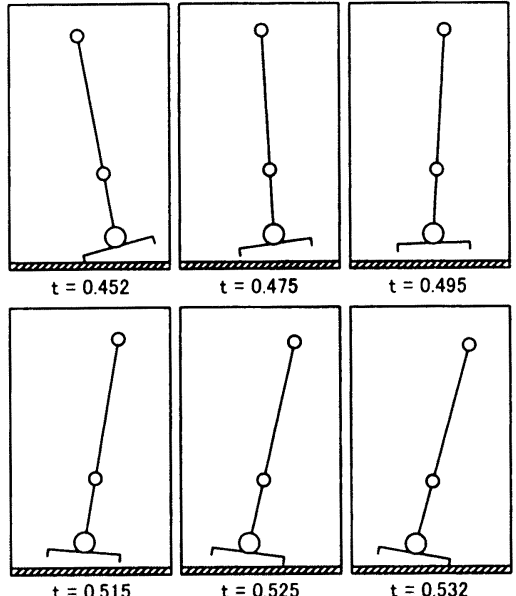

Fig. 12 Loci in phase-C (Case-2)

（4）山藤和男，三矢喜之，跳躍移動ロボットの開発と運動制御， 機論, 57-537, C (1991), 1616-1620.

（5）大久保宏樹，中野栄二，ばねとアクチュエータによる跳躍 機械の構成法, 日本ロボット学会誌, 10-7, (1992), 948954.

（6）中野栄二, 大久保宏樹，木村浩，跳躍機械の着地制御， 日本ロボット学会誌, 9-2,(1991), 169-176.

（7）小島宏行, 村上岩範, 吉田新一郎, 関谷拓, ホッピン グロボットのための 4 面包囲型リニア直流モータの開 発と連続跳躍実験, 日本ロボット学会誌, 14-1, (1996), 91-95.

（8）小島宏行、村上岩範，リニア直流モータを用いたホッ ピングロボットに関する研究（ジャイロを用いた姿勢 制御による跳躍移動運動制御）、日本 AEM 学会誌、52 , (1997), 30-36.

（9）大久保宏樹，半田実，中野栄二，自己振動を利用した 跳躍機械に関する研究（小出力アクチュエータを用い た跳躍の実現），日本ロボット学会誌，16-5，(1998), 633-639.

(10) M. D. Berkemeier and K V. Desai, Control of Hopping Height in Legged Robots Using a Neural-Mechanical Approach, Proceedings of the 1999 IEEE/RSJ International Conference on Robotics and Automation, (1999), 1695-1701.

（11）林良太，辻尾昇三，腕の振込みを応用した振子式跳躍 機械，日本ロボット学会誌，19-4, (2001), 528-534.

（12）原田望，明愛国，下条誠，梶谷誠，ゴルフスイングロ ボットに関する研究（新しい手首関節の試作とスイン グ実験），日本機械学会ロボティクス・メカトロニク 又講演会' 02 講演論文集, $1 \mathrm{Al} \cdot \mathrm{C} 11,(2002), 1 \cdot 2$.

(13) G. Kato, H. Köjma, M. Yoshida and Y. Wakabayashi, Study on Two-Link Hopping Robot with Stopper Mechanism, Proceedings of the 21st Annual Conference of the Robotics Society of Japan, 2G26, (2003), pp.1-4.

(14) G. W. Housner and D. E. Hudson, Dynamics, D. Van Nostrand Company, (1959), pp.186-191 